\title{
On the Construction of the open-university Innovation and Entrepreneurship Education System
}

\author{
YANG Bo ${ }^{1, a}$, Ge Junyi ${ }^{2, b}$, SONG Wen-yan ${ }^{1, c}$ \\ ${ }^{1}$ Chongqing Radio and TV University, Chongqing ,400052, China \\ ${ }^{2}$ Open University of China,Beijing ,100075,China \\ ayangbo74@163.com ,a178931157@163.com ,'943484588@qq.com
}

Key words: open-university, innovation and entrepreneurship education, system construction

\begin{abstract}
Innovation and entrepreneurship education, with its significant strategic importance and educational value, has aroused wide attention and has been generally recognized by general colleges and universities. Equally, the Open University developing innovation and entrepreneurship education is also great significance. What's more, comparing with general colleges and universities, it has advantages on students, teachers, and families and so on. According to the characteristics of the Open University, the innovation entrepreneurship and education system is constructed by curriculum system, capability system, practical system and security system, which makes the combination of the innovation entrepreneurship education of the Open University and professional education, faces to the needs of all students,integrates into the whole process of personnel training, and improves the students' comprehensive quality and ability.

Innovation and entrepreneurship education is the new trend of the world education development and reformation. It brings great influences and impacts on educational system educational concept talents development and other aspects of our country's colleges and universities. As the new founded Open University, its teaching model is long-distance tuition which is based on internet and its students are adult learners. These two points are different from general colleges and universities. Does it make sense for Open University carrying out innovation and entrepreneurship education? If it is meaningful, is it how to construct innovation and entrepreneurship education system? Is there any difference with the general colleges and universities? All those need us to combine the features of the Open University to do intense research.
\end{abstract}

\section{Problems Existing in General Colleges and Universities Innovation and Entrepreneurship Education System}

At first, the subject orientation of Innovation and Entrepreneurship Education is indistinct and presents marginal phenomenon. Most colleges and universities do not understand developing innovation and entrepreneurship education form the attitude of building innovation and entrepreneurship education system and talent cultivating mechanism. Therefore, innovation and entrepreneurship education has not been taken into scholastic subject construction plan,objective of talent cultivating, and quality evaluation system, which is outside the daily teaching.

Secondly, it is Separation of Innovation and Entrepreneurship Education and Professional Education System. At present, most colleges and universities have not taken innovation and entrepreneurship education into professional education talent cultivating system. Innovation and entrepreneurship education and professional education talent cultivating system are separate. It is generally believed that innovation and entrepreneurship education has no connection with professional education system. It has not realized that professional education system can be as a carrier and a supporter. There is no concept of innovation and entrepreneurship education infiltrating into professional education to form a systematized curriculum system.

Thirdly, it is Resources and Approaches Flaw in Innovation and Entrepreneurship Education. Resources and approaches flaw mainly represents as the following aspects: firstly, it is lack of excellent teachers. Innovation and entrepreneurship education requires teachers not only owning 
encyclopedic theoretical knowledge but also having abundant social experiences and practical experiences. Secondly, it is lack of outstanding teaching resources. At present, the quantity of excellent courses of innovation and entrepreneurship is less and the degree of curriculum resource sharing is low with some misnomer innovation courses. Thirdly, teaching methods are not plentiful and practical teaching is weak. In most colleges and universities, the teaching methods of innovation entrepreneurship course are mainly theory teaching and cases analysis, which can not attract students and satisfy the needs of education with simple form. ${ }^{[2]}$

\section{Advantages Analysis on Construction of Open University Innovation and Entrepreneurship Education System}

Open University is based on carrying out lifelong education for all people. ${ }^{[3]}$ The talents cultivation objectives of Open University are to combine knowledge and ability, professional education and vocational education into vocational practical talented person. The Open University education is between the professional education of colleges and universities and vocational education of higher vocational colleges. ${ }^{[4]}$ It implement vocational education by professional knowledge and vocational skills, and it is a kind of sustainable development education. ${ }^{[5]}$ It shows that The Open University constructing innovation and entrepreneurship education system meets its construction aims and cultivation object, which has great significance.

The Open University innovation and entrepreneurship education has advantages on these three aspects students, teachers, and families comparing with general colleges and universities.

At first, The Open University students are all adult working people who have some work experiences and even some entrepreneurial experience, so Open University students have much tastes and more ideas on innovation and entrepreneurship experiences. On one hand, the adult students have a certain economic base to support those developing innovation and entrepreneurship practices. On the other hand, adult students often feel pressure at work and in life, and they are eager to change their lives or create their own value by pioneering.

Secondly, in the aspect of teachers, the Open University implements distance teaching education, and it can hire senior corporate executives and entrepreneurs who have work experience and entrepreneurial experiences. They can have class by putting their class videos on the Internet for students distance learning, which can make up for their lack of teachers and is also very conducive to innovation and entrepreneurship teaching.

Thirdly, it is in the aspect of family. College students desire for innovation and entrepreneurship, but the average family does not support their business. Because their parents believe that although pioneering is very good, it is risky. And entrepreneurial success rate is very low with greater investment of resources at the beginning of the entrepreneur. Most adult students of the Open University's married, and they are more likely to get support form the family.

\section{Open University Innovation and Entrepreneurship Education System Construction}

(1) The Open University Innovation and Entrepreneurial Talents Cultivating Objects

The Open University Innovation and Entrepreneurial Talents Cultivating Objects should meet reality. Talents cultivating objective is to combine "general entrepreneurship education" which makes the entrepreneurship quality cultivation as the core and "narrow entrepreneurship education" which is to use specific entrepreneurship skills training and commercialized operation, as the main goal. It not only cultivates students' entrepreneurship, entrepreneurial consciousness, enriching their entrepreneurial knowledge and promoting their entrepreneurial ability to make them becoming "all-around talents" which suit the entrepreneurial environment; but also for the small part of the students who has strong ability and courage to start their own businesses in a bold attempt, it is to guide them materialized entrepreneurs try to develop their entrepreneurship, to cultivate them the ability of innovation to build their own businesses, to accumulate entrepreneurial experience and at last it is to make them become "professional talents" on innovation and entrepreneur. 

1.

The Open University Innovation entrepreneurial talents cultivating structure figure look at figure

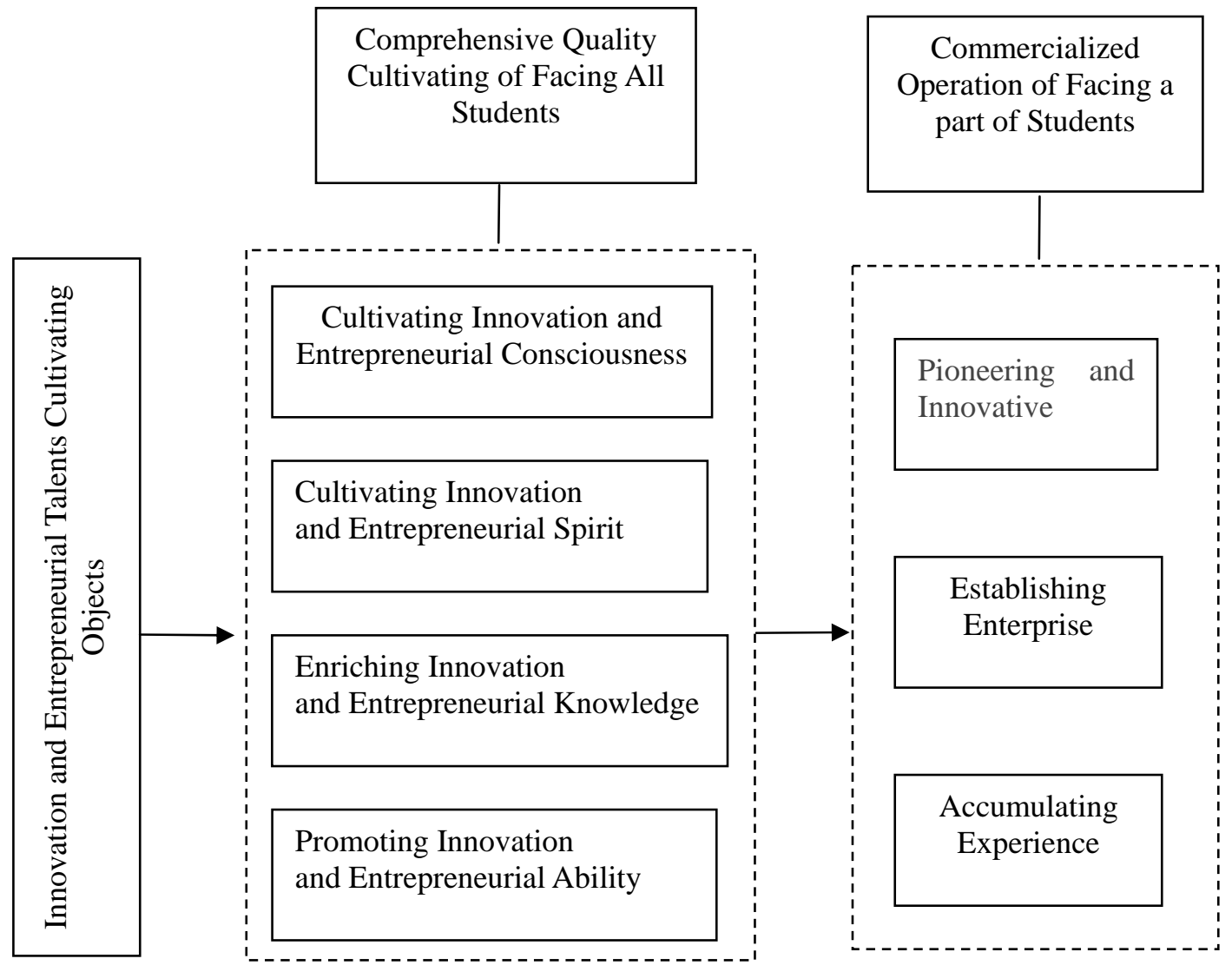

Fig. 1, Innovation and Entrepreneurial Talents Cultivating Objects Structure

(2) Open University Innovation and Entrepreneurship Education System Construction

We focused on the characteristics of the Open University, and propose that innovation and entrepreneurship education system is made up of the curriculum system, capacity system, practical system, security system. The overall idea is to adhere to the people-centered scientific concept of development, the development of students as the basis. It makes innovation and entrepreneurship education for all students, promotes the comprehensive development of students; combines of professional education, and makes personnel training integrated into the whole process.

1. Curriculum System

In curriculum setting, it follows two principles: first, innovation and entrepreneurial education is a multidisciplinary integrated subject, which need interdisciplinary and creative curriculum design. Taking innovation and entrepreneurial ideas into processional teaching should also focus on the complementarily discipline and comprehensive teaching, emphasizing the combining of theoretical courses and practical courses to form content-rich, strong operational innovation and entrepreneurship education curriculum. Secondly, innovation and entrepreneurship education should be into the normal school curriculum teaching program; positioning in the curriculum, the choice of class, the main content, teaching methods and other aspects should be clear in order to ensure students' innovative entrepreneurship education effectiveness and wide coverage.

Open University curriculum system should be modular course group, and we construct public basic modules, professional modules, practice modules, general modules these "quaternary" model of innovation and entrepreneurship education curriculum framework. Shown in Fig. 2. Public basic course module main focuses on innovation and entrepreneurial spirit, innovation and entrepreneurship awareness cultivating. Professional modules innovation and entrepreneurship 
courses should combine the specialized courses, while the professional course set up their major according to their professional features. It is focuses on enriching students' knowledge-based entrepreneurial knowledge and skills. Practical classes focus on the promoting of innovation and entrepreneurship practical capability. General curriculum for all students can open innovation case analysis, business seminars, and creative development. In teaching methods, the use of the main line of innovation and entrepreneurial process is instead of the main line of functions of management of traditional teaching methods.

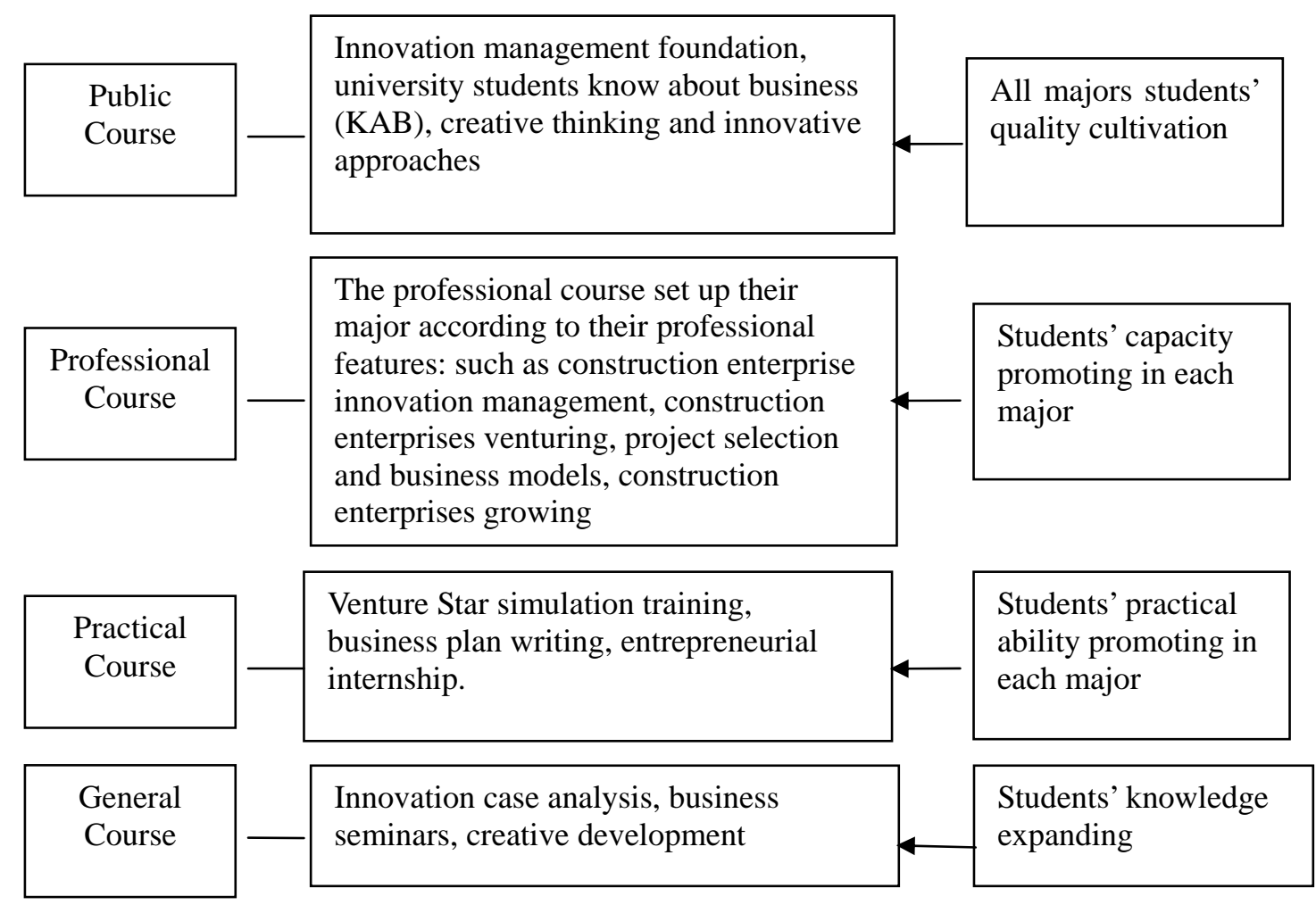

Fig. 2: Innovation and Entrepreneurship Curriculum System

\section{Ability System}

Innovation and entrepreneurship ability system is the core of the education system. For the characteristics of the Open University, we propose self-learning ability, professional ability, innovation entrepreneurship ability three progressive capability system, which are shown in Figure3.

During network environment, self-learning capability means learners who in the teacher's guidance, on its own, use a variety of learning media being initiative to acquire knowledge and skills according to their intentions, goals, plans. It is a comprehensive, integrated learning ability, including self-planning capabilities, self-control, self-evaluation skills, collaborative learning. The level of self-learning ability will directly affect the level of individual autonomy learning outcomes and the quality of online education.

Professional competence means practitioners ability to engage in an occupation that workers must have the ability include specific occupations closely related to professional competence, methods, skills and social competence. Among them, the professional competence refers to the necessary skills and knowledge with taking vocational activities, the core survival skills of workers being competent the job, and the basic ability to survive. Approach capability means having engaged in professional activities required work and learning methods is the important means for workers constantly to acquire new knowledge and skills and to learn new methods in his career. Social competence refers to required active capacity by engaging in professional activities, and is the basic qualities for workers in the occupational activities. ${ }^{[7]}$

Innovation ability broadly refers to a process which is based on learning the knowledge and 
experience being turned scientific and systematically into new ideas, new concepts, new knowledge, new methods, and being applied creatively to solve new problems. Entrepreneurship capacity includes two aspects, one is related to the ability concerning with opportunity, including the ability to identify market opportunities, the capacity to develop opportunity; the other is daily operational management capacity, including production capacity, marketing capabilities, technical capabilities, resource allocation capacity, and so on.

The ability of these three levels influences each other, complement each other, and together constitute the ability of innovation and entrepreneurship education system. Self-learning ability is the foundation, processional ability is the core, and innovation and entrepreneurial ability is ultimate goal.

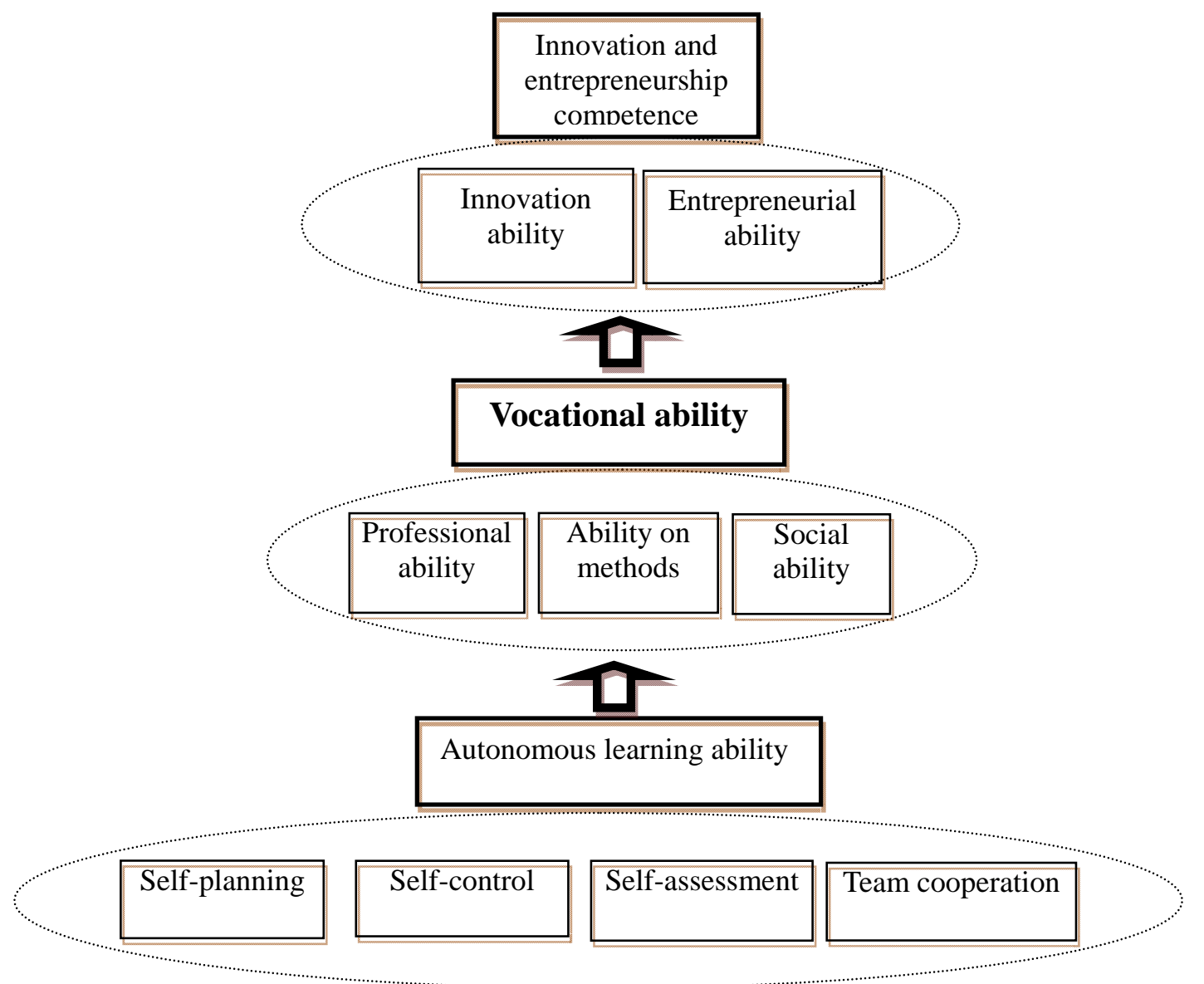

Fig. 3, Competence System “three layers progressive” Structure Chart

\section{Practical System}

Practicality of innovation and entrepreneurship education determines the innovation and entrepreneurship education which must adopt the necessary practical aspects to help the educated person training their mind, accumulation of experience, promoting capacity, casting character. The practice platform of innovation and entrepreneurship education includes on campus and off campus two platforms. Limited due to the strength of the Open University, and comparing with the inner walls of the traditional schools, campus platform is lack of laboratory facilities, limited practice cal means. The Open University has its own little business incubator or technology park, but Open University students for themselves are into the society. Therefore, the Open University practice teaching should give full play to the advantages of social relations, and vigorously promote school-enterprise cooperation, and build a real school training base, to make it become important practice platform on which Open University carry out innovation and entrepreneurship education. Secondly, vigorously to promote the combining production, to encourage students "learning by 
doing", it will turn the theory into practical work. Thirdly, to encourage students getting into the community and rural areas, to carry out social surveys, technology services and other practical activities serve the community. Entrepreneurial education is a typical "open" education fully integrating enterprise, society, schools tripartite resources, and builds up trinity, optimized and efficient entrepreneurship education practice system by schools, businesses, and society. Fourth, it is to guide students starting small and micro enterprises for entities of commercial operations.

4. Security System

The implementation of innovation and entrepreneurship education needs to have a strong security system, or it would be difficult to achieve training objectives. Security System construction can be from teaching staff security, teaching resources, management operational security, and other aspects of the specific conduct, to form three interactive security system.

(1)Teaching Staff Security

Teaching Staff is the basic guarantee of innovation and entrepreneurship. Open University's faculties of innovation and entrepreneurship education not only require a dual-qualified team, but also are very familiar with the concept of distance education and teaching methods. Therefore, the construction of an Open University faculty is to adhere to walk with two aspects. On the one hand, it should vigorously develop their own outstanding teachers who are required to have a certain time every year into enterprise, to make them familiar with enterprise; on the other hand, it should try to hire teachers who have entrepreneurial experience to do entrepreneurship courses or to hold seminars classroom teachers. By the personal experience of successful entrepreneurs, they can encourage college student's entrepreneurship, learn entrepreneurship, and teach students practical experience.

(2)Teaching Resources Security

Open University teaching resources should be "learner-centered", which are according to the wishes and needs of learners design teaching resources. Learners should consider the cultural level, level of intelligence, the ability to accept and learn the characteristics and laws of physical and mental development. It can be achieve four objectives. First, it helps to achieve effective learning, so that students can spend less time to acquire more knowledge. It makes learning funnier and more tightly connecting with life practice. Second, it helps to achieve learning at anytime and in anywhere, so that it makes digital resources through diverse mobile terminals spread. Third, it helps to achieve self-learning and interaction. Fourth, it helps students to cultivate application skills.

(3) Management Operation Security

Its main tasks are to carry out theoretical research innovation and entrepreneurship education, to draft policies encouraging and supporting students start to develop entrepreneurship, to stimulate students' entrepreneurial desire to create a good business climate; its tasks are to check and guide students in entrepreneurial projects, to establish of a special fund for business students, to aid the students' scientific and technological inventions, and their own businesses; its tasks are to build entrepreneurial information service network, to establish entrepreneurial information tracking system to collect feedback for students in school and out school, with the help of students' feedback timely correcting innovation and entrepreneurship education system and continuously improving the quality of teaching quality of innovation and entrepreneurship education.

\section{Conclusion}

Open University to carry out innovation and entrepreneurship education is a new subject. We focused on the characteristics of the Open University constructing the Open University innovation and entrepreneurship education system of 4333. It respectively includes public basic courses, professional courses, practical courses, general courses these four curriculum modules. It includes self-learning ability, professional competence, innovation and entrepreneurship ability these three progressive systems. It includes schools, businesses, and social Trinity practice system. It includes teaching staff security, teaching resources security, management operations security these three interactive security system. The paper proposes innovation and entrepreneurship education system also need to open the actual running system in universities and constantly to revise according to 
practical effect. It hopes that Open Universities open innovation and entrepreneurship education to enhance students' comprehensive quality and innovation capability and to enhance the educational quality of Open University.

\section{References}

[1] Li Jiahua, Lu Xudong.. The Innovation and Entrepreneurship Education into University Personnel Training System [J]. China Higher Education, 2010 (12).

[2] Peng Wenbo, etc. Construction of Innovation and Entrepreneurship Education Curriculum Exploration and Practice [J]. Innovation and Entrepreneurship Education, 2010 (4)

[3] Kang Ping. On the Open University Professional and Curriculum System - Based on the Construction of Lifelong Education System [J]. China Distance Education, 2012 (6)

[4] Central Radio and Television University. National Open University building programs [R]. Beijing: China Central Radio and Television University Press, 2011.

[5] Ji Ping, Yang Ting-ting, LI Song. Open University Discipline Construction [J]. Modern Distance Education, 2012 (2): 28-33

[6] Cao Shengli, Ray Jiasu. Chinese universities need what kind of innovation and entrepreneurship education [N]. China Education Daily, 2010-1-13.

[7] Weisheng Qi, He Miao. Emphasis on professional competence cultivation mode Transformation - Based on Students' professional competence, Sichuan Investigation [J]. Modern Distance Education Research, 2012 (1):80-86

About the author:

1. Yang Bo (1974 -), male, Han, Economics and Business Administration College of Chongqing University, PhD; Finance and Economy Department of Chongqing Radio and Television University, vice professor, vice president; Main research directions: modern distance education, innovation and entrepreneurship education

2. Ge Junyi (1982 -) female, Han, Finance and Economics College of Open University of China, postdoctoral,vice professor; main research directions: modern distance education, innovation and entrepreneurship education

3.Song wenyan(1984 -) female, Han, Finance and Economy Department of Chongqing Radio and Television University, Main research directions: modern distance education, innovation and entrepreneurship education

Contact: Tel: 15086821550, Email: yangbo74@163.com

Address: Finance and Economics Management Departmwnt of Chongqing Technology and Business Vocational Institute, Siyuan Road 15, HeChuan District, ChongQing

Code: 401520 